\title{
Reassessment of cyperaceous weed biodiversity at Bangladesh Agricultural University campus
}

\author{
Jannat-E-Tajkia, Ashaduzzaman Sagar and A.K.M. Golam Sarwar
}

Department of Crop Botany, Bangladesh Agricultural University, Mymensingh 2202, Bangladesh

\begin{tabular}{|c|c|}
\hline ARTICLE INFO & Abstract \\
\hline $\begin{array}{l}\text { Article history: } \\
\text { Received: } 31 \text { May } 2018 \\
\text { Accepted: } 09 \text { August } 2018\end{array}$ & $\begin{array}{l}\text { A floristic survey has been carried out from January } 2015 \text { to January } 2016 \text { to investigate the species } \\
\text { diversity of Cyperaceous weeds present at Bangladesh Agricultural University campus. A total of } 48 \\
\text { species belonging to } 11 \text { genera has been collected and identified. Among these, the prominent genus was } \\
\text { Fimbristylis ( } 13 \text { species) followed by Cyperus (12 species) and three genera viz. Actinoscirpus, }\end{array}$ \\
\hline $\begin{array}{l}\text { Keywords: } \\
\text { Climate change, diversity status, } \\
\text { economic uses, sedges, weed } \\
\text { management }\end{array}$ & $\begin{array}{l}\text { Bolboshoenus and Fuirena were represented by single species. Result of the present study revealed that } \\
\text { some of these species are major and common obnoxious weeds in different crop fields. A good number of } \\
\text { these species have great medicinal uses, fodder, raw materials for small industries and other economic } \\
\text { values. The detailed taxonomic studies of these weeds will be helpful for the management practices of } \\
\text { Cyperaceous weeds at this campus as well as in the whole country. It might be concluded that }\end{array}$ \\
\hline $\begin{array}{l}\text { Jannat-E-Tajkia } \\
\text { (jetajkia@bau.edu.bd) }\end{array}$ & $\begin{array}{l}\text { elopment of improved cultivation procedures will be helpful for getting high economic benefits from } \\
\text { peraceous weeds without affecting our crop yield and agro-ecosystem. There is no direct evidence of } \\
\text { nate change threatening or eliminating Cyperaceae taxa from this locality. }\end{array}$ \\
\hline
\end{tabular}

\section{Introduction}

Cyperaceae, commonly known as sedges, is one of the largest monocotyledonous families with 5,500 known species described in about 90 genera (Christenhusz and Byng, 2016). Many species of sedges have evolved as weeds (Bryson and Carter, 2008). Weeds of the cyperaceae family are widely distributed in tropical Asia and South America with various harmful, taxonomic, ethno-botanical and horticultural importance. These weeds can grow in diverse environments and compete with crop plants for space, food, water, light environment, etc. Weeds generally have no positive economic importance in agriculture/production system, though in some cases weeds also have some beneficial uses - forage, soil binder, medicinal, raw materials for small industries, etc.

The Bangladesh Agricultural University (BAU) campus is positioned under the Agro-Ecological zone 9 i.e., Old Brahmaputra Floodplain; roughly the whole area can be divided into three main topographic types - basinshaped low lying area, slightly undulated area and plain area. The campus exhibit diverse habitats, such as marshy land, wetland, crop fields, fallow lands, etc. which support abundance growth of sedges in this campus (Sarwar and Prodhan, 2011). Agricultural productivity, human health and livestock are adversely affected by weedy sedges due to competition for natural resources with crops; allergens \& anti-nutrition compounds for human and livestock.
Weeds cost billions of dollars in agriculture, forestry, and urban areas and threaten diversity in natural communities worldwide. Of an estimated 8,000 species of weeds worldwide, only about 200 species cause 95\% of the problems in production of food, feed, fibre, and livestock (Bryson and Carter, 2008). About 25\% of the world's weeds are monocots (Bryson and Carter, 2008). In Bangladesh, the increase of population growth and the low yields of crops are the main reasons for severe food deficits every year. Through proper weed management practices, the production of food grains can be increased (Karim, 1998). An up to date knowledge on different weed species of Bangladesh is essential to manage them below threshold level for sustainable crop production and/or to use them for our economic benefit especially the sedges as their control is very difficult. The taxonomic study of this family is still unattended in the "Flora of Bangladesh". Some information is available as a part of other Agronomic or Horticultural research (Huda et al., 2017 and older references therein). Two significant research works were carried out on the sedges of BAU campus, one in early seventies (Anwer, 1971) and the other is originally a relatively older work (during 2000-2002) published recently (Sarwar and Prodhan, 2011). The objective of this present study to update our knowledge on biodiversity of sedges at the Bangladesh Agricultural University campus including their habitat, flowering times, and other uses; which may be helpful for the green management practices and for getting higher economic benefits from Cyperaceous weeds without affecting our crop yield and agro- 
ecosystem. The other objective is to use Cyperaceae as a model family (Simpson et al., 2011) for climate change work on biodiversity and conservation of this campus.

\section{Materials and Methods}

An intensive field survey of Cyperaceous weeds growing throughout the BAU campus was carried out during January 2015 to January 2016. Frequent visits were made to assess the flowering time of these species. The fresh plant samples/specimens were collected at the flowering stage and other relevant information e.g., location, date, habitat, crop/plant association, etc. were recorded. Plant samples were properly dried for making voucher specimens. The fresh and/or dried specimens were identified in the field or by matching with herbarium specimens and/or published literature or consulting with experienced taxonomist at the Bangladesh National Herbarium, Dhaka. All the specimens are preserved in Prof. Dr. Arshad Ali Herbarium at the Botanical Garden, Department of Crop Botany, Bangladesh Agricultural University. The major literature consulted was "Encyclopedia of Flora and Fauna of Bangladesh (Siddiqui et al., 2007) and other taxonomy related books (Sarwar and Prodhan, 2011 for details).

\section{Results and Discussion}

The species collected and identified are presented in Table 1 with their botanical names, common \& English name, habitat, flowering time and other uses. A total of 48 species belong to 11 genera were identified. Among them, the prominent genus was Fimbristylis (13 species) followed by Cyperus (12 species), Pycreus (6), Eleocharis (5) and Kyllinga (3); three genera viz. Actinoscirpus, Bolboshoenus and Fuirena were represented by single species (Fig. 1). Species reported in this paper occupy diverse habitat such as various crop fields, wetlands, open grasslands, waysides, marshy places, riverbank and the bank of other water reservoirs, etc. Most of them are very common in rice fields, especially the species of the genus Fimbristylis, Pycreus, Cyperus, Eleocharis, etc. (Table 1).

The control methods used for weedy sedges are much diversified such as cultural methods, mechanical tillage, chemical treatments, shading with cover crops or black plastic, etc. (Bryson and Carter, 2008). The knowledge of flowering period may play a very important role for the controlling of weedy sedges. For example, flowering period of collected species showed a wide range of variation like Rabi season, Kharif season or all the year around (Table 1). If we uproot sedges before attaining the flowering stage, their propagation and spreading will be reduced. Moreover, we can easily take the appropriate methods for controlling the weeds according to their habitat.
Comparing with the previous study of Sarwar and Prodhan (2011), the presence of seven species viz. Eleocharis retroflexa, Fimbristylis falcata, Kyllinga brevifolia, K. cylindrica, Pycreus polystachyos, P. sanguinolentus and Scirpus triqueter var. segregatus, has newly been identified (with * in Table 1, Fig. 2). The number of genera represented by single species decreased from five to three (Anwer, 1971) which might be due to the identification of new species for any of these genera, as the numbers of species have been increased. These may support Simpson et al. (2011) who concluded that some species of Cyperaceae appear to be vulnerable, although, as yet, there is no direct evidence of climate change threatening or eliminating taxa. The occurrence of new species may be for various reasons; first of all, it may exist in this locality but somehow unidentified/missed during the previous studies. Secondly, anthropogenic activities may act as a vector to introduce these species from other location with various crop seeds. Among these, Kyllinga brevifolia, Scirpus triqueter are edible and used as fodder, so they may be dispersed here through grazing animals. Cyperaceae are especially important forage genetic resources in cold, damp sites, Carex and Cyperus are locally common and Kobresia covers large areas of the closely grazed mountain meadow in Himalaya and China (Ruijun, 2003). Moreover, they may be introduced here due to winds, flying animals (birds), water currents, changing cropping pattern, etc.

Most of the studied species are major and common weeds of various crop fields e.g., rice, jute, wheat, etc. and some of them act as obnoxious weeds. Some species have various medicinal values e.g., Cyperus rotundus, used in leprosy, thirst, fever, blood diseases, biliousness, dysentery, pruritus, pain, vomiting, urinary concertinas, stomach disorder and irritation of the bowels etc. Moreover, Cyperus laxus, Scirpus articulatus and some other species have also some important medicinal values. Some species are used as fodders in different countries such as Cyperus difformis, Fimbristylis milliaceae, Kyllinga brevifolia, K. monocephala, etc. Some species of the genus Pycreus, Cyperus flavidus, etc. act as a soil binder. Fimbristylis schoenoides and some other species are used to make green manures. Some species have various ethno-botanical importances such as Actinoscirpus grossus, Cyperus iria, C. babakan, etc. These are used to make the mat, bags, various handicrafts, etc. (Table 1). Water treatments using Cyperaceae have demonstrated up to 92\% removal of total nitrogen (Tanner, 1996) and significant sequestration of metals such as copper (Murray-Gulde et al., 2005). 


\section{Table 1. Cyperaceous weeds in the Bangladesh Agricultural University campus}

\begin{tabular}{|c|c|c|c|c|c|}
\hline Botanical name & Common name & English name & Habitat & Flowering time & Harmful aspects and economic uses \\
\hline $\begin{array}{l}\text { Actinoscirpus grossus (L.f.) Goetgh. } \\
\text { \& D.A. Simpson }\end{array}$ & Kasari & Giant Bulrush & Swamps, ditches, rice fields & August-December & $\begin{array}{l}\text { Making sleeping mats, bags and baskets. In some } \\
\text { countries, used as fodder \& medicinal, major weed in rice } \\
\text { fields. }\end{array}$ \\
\hline $\begin{array}{l}\text { Bolboshoenus maritimus (L.) Palla } \\
\text { subsp. affinis (Roth) T. Koyama }\end{array}$ & _ & Purua grass & Rice fields and swamp lands. & March-August & Food (rhizome), Medicine, fibre, aquatic weed. \\
\hline Cyperus babakan Steud. & _ & & Rice fields and swamp lands. & May-October & Acts as a weed of open marshy places. \\
\hline Cyperus compactus Retz. & - & Compact Sedge & $\begin{array}{l}\text { Wet grassy places, margin of pond and } \\
\text { ditches and rice fields. }\end{array}$ & September-March & Considered a weed of rice fields \\
\hline Cyperus compressus L. & Chanch & $\begin{array}{l}\text { Poor land Flat- } \\
\text { sedge }\end{array}$ & $\begin{array}{l}\text { Open grasslands, waste places, waysides, } \\
\text { cultivated grounds }\end{array}$ & Year around & Food (rhizome), A common weed of agricultural lands. \\
\hline $\begin{array}{l}\text { Cyperus corymbosus Rottb. var. } \\
\text { longispiculatus (O. Ktze.) Kük. }\end{array}$ & Gola methi & Chinese matgrass & Wet, swampy and marshy fields & Year around & $\begin{array}{l}\text { Its straight culm used for making a kind of rough mat, } \\
\text { tuber used as a tonic and stimulant. }\end{array}$ \\
\hline Cyperus difformis L. & $\begin{array}{l}\text { Behua/sabuj } \\
\text { nakphul }\end{array}$ & $\begin{array}{l}\text { Small flower } \\
\text { Umbrella plant }\end{array}$ & $\begin{array}{l}\text { Wet, swampy and grassy fields and bamboo } \\
\text { grooves. }\end{array}$ & Year around & $\begin{array}{l}\text { Competes with the rice plants for nutrients, water and } \\
\text { light. Occasionally the plant is eaten by cattle. }\end{array}$ \\
\hline Cyperus flavidus Retz. & - & $\begin{array}{l}\text { Yellow } \\
\text { flatsedge }\end{array}$ & $\begin{array}{l}\text { Open wet places, often as a weed of } \\
\text { inundated rice fields. }\end{array}$ & Year around & $\begin{array}{l}\text { A principal rice weed in Bangladesh, India, Indonesia, Sri } \\
\text { Lanka and Vietnam. }\end{array}$ \\
\hline Cyperus iria L. & Bara chucha & Umbrella sedge & $\begin{array}{l}\text { Rice fields, cultivated grounds and way } \\
\text { sides. }\end{array}$ & Year around & $\begin{array}{l}\text { A common weed of cultivated lands, plant used for } \\
\text { making mat. }\end{array}$ \\
\hline Cyperus laxus Lamk. var. laxus & & & Wet lands and bamboo grooves. & Year around & In Mindanao, the roots used as medicine for diseased lips. \\
\hline Cyperus michelianus (L.) Link. & Choto Gotubi & Michel sedge & $\begin{array}{l}\text { Open, moist or rather dry grounds, grassy } \\
\text { fields, roadsides and river banks. }\end{array}$ & September-February & A weed of rice fields. \\
\hline Cyperus pilosus Vahl & - & Fuzzy flat sedge & Open wet places, grass land, rice fields & Year around & A weed of wet and waste places. \\
\hline Cyperus platystylis R.Br. & $\begin{array}{l}- \\
-\end{array}$ & - & $\begin{array}{l}\text { Very wet places in swamps, margins of } \\
\text { pools, wet rice fields. }\end{array}$ & November-February & A weed of rice fields, cattle fodder. \\
\hline Cyperus rotundus L. & $\begin{array}{l}\text { Mutha/ } \\
\text { Nagar Mutha }\end{array}$ & Purple nutsedge & $\begin{array}{l}\text { Road sides, waste places, open or slightly } \\
\text { shaded grounds. }\end{array}$ & May-September & $\begin{array}{l}\text { A serious pest in the cultivated lands. Young tubers eaten } \\
\text { as food (sometimes), tubers used in leprosy, thirst, fever, } \\
\text { blood diseases, biliousness, dysentery, pruritus, pain, } \\
\text { vomiting, urinary concertinas, stomach disorder and } \\
\text { irritation of the bowels. }\end{array}$ \\
\hline Eleocharis atropurpurea Kunth & Pani chaise & Purple spike-rush & $\begin{array}{l}\text { Wet areas, rice fields, bank of river and } \\
\text { lakes. }\end{array}$ & November- January & - \\
\hline $\begin{array}{l}\text { Eleocharis geniculata (L.) Roem. \& } \\
\text { Schult. }\end{array}$ & - & $\begin{array}{l}\text { Canada spike- } \\
\text { sedge }\end{array}$ & Rice fields and swampy grasslands & November-February & A weed of rice fields. \\
\hline Eleocharis palustris (L.) R.Br. & & $\begin{array}{l}\text { Common spike- } \\
\text { rush }\end{array}$ & $\begin{array}{l}\text { Wet grassy places, margin of pond and } \\
\text { ditches and rice fields. }\end{array}$ & October-February & A minor weed of rice fields. \\
\hline Eleocharis plantaginea $R . B r$. & - & $\begin{array}{l}\text { Chinese water } \\
\text { chestnut }\end{array}$ & Open swamps, wet floors and marshy places & May-December & Corms of the plants eaten as raw or cooked in China \\
\hline *Eleocharis retroflexa (Poir.) Urb. & _- & $\begin{array}{l}\text { Coastal plain } \\
\text { spike-rush }\end{array}$ & $\begin{array}{l}\text { Wet grassy places, margin of pond and } \\
\text { ditches and rice fields. }\end{array}$ & October to February & A minor weed of rice fields. \\
\hline Fimbristylis acuminata Vahl & - & $\begin{array}{l}\text { Pointed } \\
\text { Fimbristylis }\end{array}$ & Open wet and muddy places. & October-March & A weed of rice fields. \\
\hline Fimbristylis aestivalis (Retz.) Vahl & & Summer Fimbry & Rice fields, Open wet places. & September-February & A weed of rice fields. \\
\hline
\end{tabular}




\section{Table 1. Cont.}

\begin{tabular}{|c|c|c|c|c|c|}
\hline Botanical name & Common name & English name & Habitat & Flowering time & Harmful aspects and economic uses \\
\hline $\begin{array}{l}\text { Fimbristylis dichotoma (L.) Vahl } \\
\text { subsp. Dichotoma }\end{array}$ & Bara nirbishi & Tall fringe-rush & Open wet places. & August-December & A weed of rice fields. \\
\hline $\begin{array}{l}\text { Fimbristylis dipsacea (Rottb.) } \\
\text { Clarke }\end{array}$ & - & - & $\begin{array}{l}\text { Moist riverbank, margin of lake and } \\
\text { swamps. }\end{array}$ & Year around & A weed of waste land. \\
\hline Fimbristylis diphylla (Retz.) Vahl & Mati chaise & $\begin{array}{l}\text { Common fringe- } \\
\text { sedge }\end{array}$ & Wet grassy places, margin of rice fields. & Year around & A weed of rice fields. \\
\hline${ }^{*}$ Fimbristylis falcata (Vahl) Kunth & Bindi mathi & - & Open grassland & April-December & $\begin{array}{l}\text { A weed of waste land, medicinal use in dysentery, skin } \\
\text { diseases and ringworms. }\end{array}$ \\
\hline Fimbristylis hookeriana Boeck. & & & Open wet places & Year around & Often as a weed of inundated rice fields. \\
\hline Fimbristylis milliaceae Vahl & Joina/Bara Javani & $\begin{array}{l}\text { Grass-like } \\
\text { Fimbristylis }\end{array}$ & Rice Fields and wet places & May-November & $\begin{array}{l}\text { A common weed of paddy fields competing with paddy } \\
\text { for nutrients and sunlight }\end{array}$ \\
\hline Fimbristylis monostachyos Hassk. & & Marmari & Wet grass land & Year around & A weed of waste land. \\
\hline $\begin{array}{l}\text { Fimbristylis polytrichoides (Retz.) } \\
\text { R.Br. }\end{array}$ & - & Rusty sedge & Open places & August-January & Acts as a good soil binder \\
\hline Fimbristylis quinquangularis Kunth & - & $\begin{array}{l}\text { Grass like } \\
\text { Fimbry }\end{array}$ & Open wet grasslands, cultivated rice fields & June-November & $\begin{array}{l}\text { A weed of rice fields, to make green manure, medicinal } \\
\text { use in fever. }\end{array}$ \\
\hline $\begin{array}{l}\text { Fimbristylis schoenoides (Retz.) } \\
\text { Vahl }\end{array}$ & Keshari & Ditch Fimbry & Wet open grassland and rice fields & July-November & $\begin{array}{l}\text { The plant forms a fair proportion of the weeds of } \\
\text { somewhat dry rice fields, sometimes used to make green } \\
\text { manure. }\end{array}$ \\
\hline Fimbristylis squarrosa Vahl & Jumka chaich & & Shores of lakes and wet sandy soils & June-November & A weed of rice fields, medicinal use in sore throat. \\
\hline Fuirena ciliaris (L.) Roxb. & Choto nolchok & Ümbrella grass & Open wet or swampy places. & September-February & A weed of cultivated fields. \\
\hline *Kyllinga brevifolia Rottb. & - & Green Kyllinga & $\begin{array}{l}\text { Sunny and somewhat shaded places and } \\
\text { grassy fields }\end{array}$ & March-September & $\begin{array}{l}\text { Sometimes used as fodder for cattle and horses, has } \\
\text { satisfactory food value with scanty yield. }\end{array}$ \\
\hline *Kyllinga cylindrica Nees in Wight & - & $\begin{array}{l}\text { Fragrant spike- } \\
\text { rush }\end{array}$ & Open grass land & July-November & - \\
\hline Kyllinga monocephala Rottb. & - & $\begin{array}{l}\text { Whitehead spike- } \\
\text { sedge }\end{array}$ & $\begin{array}{l}\text { Sunny and somewhat shaded waste land, } \\
\text { Road sides, Grassy fields. }\end{array}$ & June-September & $\begin{array}{l}\text { Fodder for cattle and horses in drier areas, possesses } \\
\text { satisfactory food value. }\end{array}$ \\
\hline Lipocarpha spacelata Kunth & & Half-chaff sedges & Open wet ground, margin of swamps & September- January & A weed of wet lands. \\
\hline Lipocarpha squarrosa (L.) Goetgh. & Guri & Half-chaff sedges & $\begin{array}{l}\text { Open wet sandy or clay soils at margins of } \\
\text { pond }\end{array}$ & September- January & A weed of waste land. \\
\hline $\begin{array}{l}\text { Pycreus capillaris (Koen. ex Roxb.) } \\
\text { Nees var. stricta Clarke }\end{array}$ & - & - & $\begin{array}{l}\text { Open wet places, swamp, grassy fields and } \\
\text { rice fields. }\end{array}$ & July-November & A weed of rice fields. \\
\hline $\begin{array}{l}\text { Pycreus diaphanus (Schhrad. ex } \\
\text { Roem. \& Schult.) Hooper \& Koyma }\end{array}$ & - & - & Grasslands. & April-September & A weed of rice fields. \\
\hline *Pycreus polystachyos Rottb. & - & $\begin{array}{l}\text { Bunchy sedge/ } \\
\text { Field sedge }\end{array}$ & $\begin{array}{l}\text { Open, moist or rather dry grounds, grassy } \\
\text { fields, roadsides and river banks. }\end{array}$ & June-October & A weed, act as a soil binder. \\
\hline Pycreus pumilus (L.) Nees & - & Low flat-sedge & $\begin{array}{l}\text { Open wet to semidry grassy and sandy } \\
\text { fields }\end{array}$ & August-February & A weed of waste lands, acts as a soil binder. \\
\hline $\begin{array}{l}\text { *Pycreus sanguinolentus (Vahl) } \\
\text { Nees }\end{array}$ & Satidhara & $\begin{array}{l}\text { Louisiana flat- } \\
\text { sedge }\end{array}$ & $\begin{array}{l}\text { Wet grassy fields, ditches, margins of } \\
\text { swamps and rice fields. }\end{array}$ & August-February & A weed of rice fields. \\
\hline Pycreus stramineus Clarke & & & Wet grassy places and rice fields. & August-October & A weed of rice fields. \\
\hline $\begin{array}{l}\text { Schoenoplectus juncoides (Roxb.) } \\
\text { Palla }\end{array}$ & C̄hisra & $\begin{array}{l}\text { Hard-stem } \\
\text { bulrush }\end{array}$ & $\begin{array}{l}\text { Wet grassy places, margin of pond and } \\
\text { ditches and rice fields. }\end{array}$ & Year around & A weed of rice fields. \\
\hline Schoenoplectus supinus (L.) Palla & & & Open wet marshy lands & August-February & A weed of rice fields. \\
\hline Scirpus articulatus $L$. & Putputi-Chechra & Bulrush & Open marshy places, rice fields. & October-March & Used as a purgative, considered as a weed of rice fields. \\
\hline $\begin{array}{l}\text { *Scirpus triqueter (L.) Palla var. } \\
\text { segregatus C.B. Clarke }\end{array}$ & - & Triangular rush & Open marshes, freshwater swamps. & December-March & Edible seeds and roots. \\
\hline
\end{tabular}

*indicates newly identified species 
Tajkia et al.

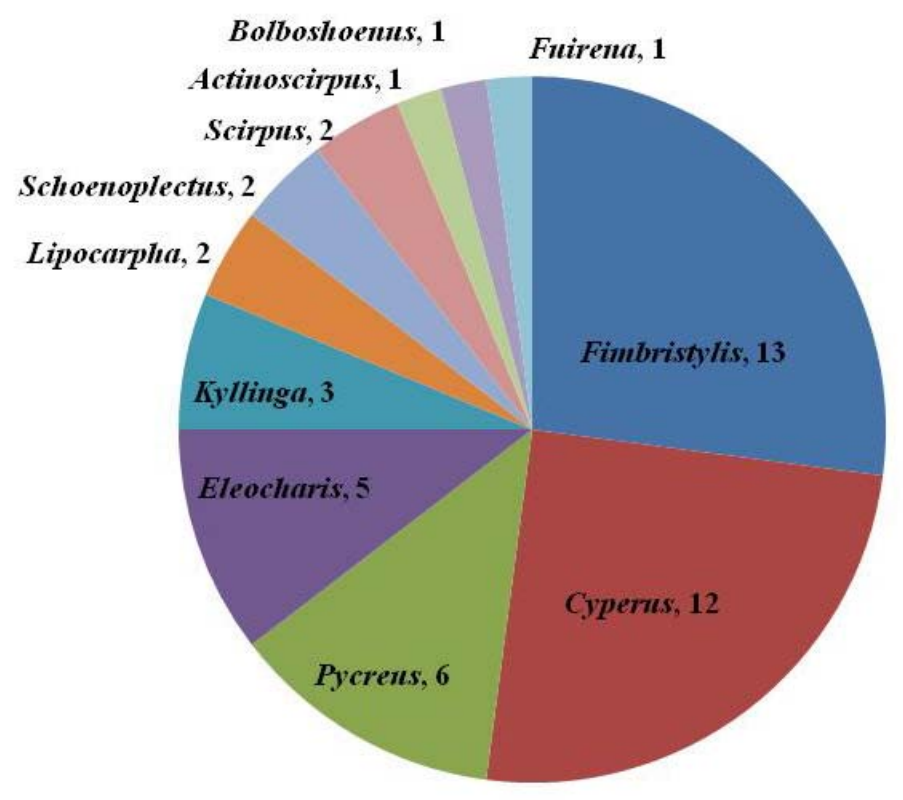

Fig. 1. Cyperaceous weed genera (number of species) present in Bangladesh Agricultural University Campus
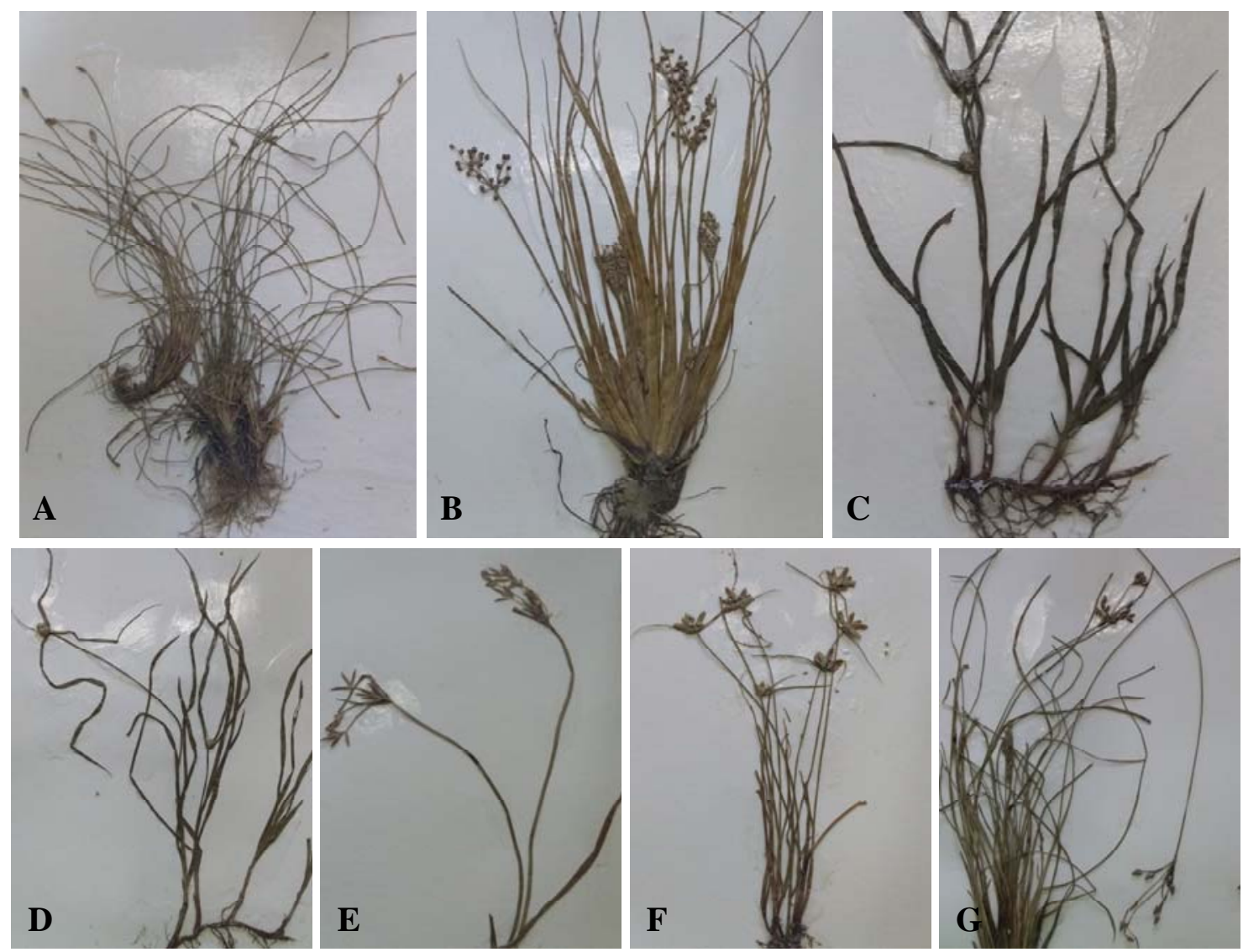

Fig. 2. Newly identified species apart from Sarwar and Prodhan (2011). A. Eleocharis retroflexa, B. Fimbristylis falcata, C. Kyllinga brevifolia, D. Kyllinga cylindrica, E. Pycreus polystachyos, F. Pycreus sanguinolentus, G. Scirpus triqueter var. segregatus 


\section{Conclusion}

Results of the present study revealed that weeds of the family Cyperaceae are widely distributed in Bangladesh Agricultural University campus. Some species are major and common obnoxious weeds for rice and other crop fields. A good number of these species have various medicinal and other values. It may be concluded that knowledge generated from the present research would be helpful for the management practices of weed sedges as well as for getting benefits from other uses of different species. The micro-site (BAU campus) climate change has little or no effect on Cyperaceous weed biodiversity of this campus.

\section{Acknowledgement}

We indebted to Dr S Nasir Uddin, Principal Scientific Officer, Bangladesh National Herbarium for identification of some of the specimens, and acknowledge the National Science and Technology Fellowship (to $1^{\text {st }} \& 2^{\text {nd }}$ author), the Ministry of Science and Technology, Government of the People's Republic of Bangladesh.

\section{References}

Anwer, S.K. 1971. The Sedges of East Pakistan Agricultural University Campus. M.Sc. thesis, Department of Crop Botany, Bangladesh Agricultural University, Mymensingh. pp. 1-74.

Bryson, C.T. and Carter, R. 2008. The significance of Cyperaceae as weeds. Monograph Systematic Botany Missouri Botanical Garden, 108: 15-101.

Christenhusz, M.J. and Byng, J.W. 2016. The number of known plants species in the world and its annual increase. Phytotaxa, 261: 201-217.
Huda, M., Begum, M., Rahman, M.M. and Akter, F. 2017. Weed composition study on wheat and boro rice in research and farmers' fields. Journal of the Bangladesh Agricultural University, 15: 148-157.

Karim, S.M.R. 1998. Relative yields of crops and crop losses due to weed competition in Bangladesh. Pakistan Journal of the Scientific and Industrial Research, 41: 318-324.

Murray-Gulde, C.L., Huddleston, G.M., Garber, K.V. and Rodgers, J.H. 2005. Contributions of Schoenoplectus californicus in a constructed wetland system receiving copper contaminated wastewater. Water, Air and Soil Pollution, 163: 355-378.

Ruijun, L. 2003. Yak nutrition - a scientific basis. In: Wiener, G. Jianlin, H. and Ruijun, L. (eds). The Yak. $2^{\text {nd }}$ ed. FAORAP Publication 2003/06, Bangkok. http://www.fao.org/documents/show_cdr.asp?url_file=/DOC REP/006/AD347E/ad347e07.htm

Sarwar, A.K.M. Golam and Prodhan, A.K.M.A. 2011. Study on the Cyperaceous weeds of Bangladesh Agricultural University campus. Journal of Agroforestry and Environment, 5: 89-91.

Siddiqui, K.U., Islam, M.A., Ahmed, Z.U., Begum, Z.N.T., Hassan, M.A., Khondker, M., Rahman, M.M., Kabir, S.M.H., Ahmad, M., Ahmed, A.T.A., Rahman, A.K.A. and Haque, E.U. (eds) 2007. Encyclopedia of Flora and Fauna of Bangladesh, Vol. 11. Angiosperms: Monocotyledons (Agavaceae-Najadaceae). Asiatic Society Bangladesh, Dhaka, pp. 1-399.

Simpson, D.A., Yesson, C., Culham, A., Couch, C.A. and Muasya, A.M. 2011. Climate change and Cyperaceae. In: Hodkinson, T., Jones, M., Waldren, S. and Parnell, J. (eds.). Climate Change, Ecology and Systematics. Cambridge University Press, pp. 439-456. Available at http://centaur. reading.ac.uk/20419/

Tanner, C.C. 1996. Plants for constructed wetland treatment systems: a comparison of the growth and nutrient uptake of eight emergent species. Ecological Engineering, 7: 59-83. 